\title{
Call for UK investment
}

THE remote sensing market is an essential area for UK involvement, according to a report on Remote Sensing and Digital Mapping (HMSO, £7) produced last week by the House of Lords Select Committee on Science and Technology. And while the government is asked to increase investment in selected areas, most of the report's 52 recommendations concern changes in the infrastructure of the remote sensing and mapping communities. In particular, there is a call for greater effort in the handling and intepretation of digital data and the development of a network of linked computers in key centres.

The committee highlights the market potential of remote sensing, especially the current investment in the United States and France in satellite imaging systems. A major recommendation is that the National Remote Sensing Centre at the Royal Aircraft Establishment, Farnborough, should be given more staff and become the central "executive" node of a national computer network - a role similar to that of the Rutherford Appleton Laboratory in the astronomers' 'Starlink' network.

The aim would be to enhance the general accessibility of remote sensing data. The committee emphasizes that a significant challenge for the future will come not so much from advances in satellite instrumentation (although increased spectral resolution and radar sensivitity are two key areas of research) but through the sheer volume of data that such technical advances will produce. Two areas of strength, therefore, on which the United Kingdom should build are remote sensing radar and software development.

On satellite vehicles themselves, the committee advocates enthusiastic participation in European Space Agency projects such as ERS-1 - a remote sensing satellite due for launch in 1986 - but also bilateral collaborations, particularly with the United States and Canada.

Another important recommendation is that there should be a formal link between the research councils in the form of a joint committee for basic research. This is likely to be welcomed by those working on the proposed Satellite Radar Altimetry project (see Nature 306, 108; 1983) now under consideration by the Natural Environment Research Council and the Science and Engineering Research Council. The project is not only costly (requiring about $£ 18$

\section{Correction}

SIR Peter Hirsch's share of the 1983-84 Wolf Foundation prize in physics was for his contributions to the utilization of the transmission electron microscope and not the scanning electron microscope as claimed in Nature 2 February, p.407. million over ten years) but also falls within both councils' areas of responsibility, and, as a result, has encountered difficulties. Yet its supporters argue that it would incorporate the development of just the sort of expertise in instrumentation and datahandling that the House of Lords committee seeks.

Philip Campbell

- The report also concludes that the Ordnance Survey should increase its qualified research and development staff if it is to maintain its leading role among British mapping agencies and that the survey's digitization programme should be speeded up.

These conclusions will be as music to the ears of Ordinance Survey staff, who have been facing an uncertain future. Formally, the survey is a government department financed on a vote from central funds. A plan last year to re-establish it as a "trading fund" met with a chorus of protest from a variety of Ordnance Survey users, and was defeated in the House of Lords. Last month Mr Patrick Jenkin, Secretary of State for the Environment, announced that the survey will remain on voted funds but will be required to work to clearly defined financial targets.

The digital mapping programme is very much in its infancy but the committee believes - and some at the survey are ready to agree - that demand for digital maps is likely to increase because they can be displayed or printed very rapidly, to a variable scale and with user-defined edges. Moreover, particular features can be emphasized, or omitted for clarity, and digital maps are easily updated.

The committee wants a reversal of the recent "insensitively applied" manpower cuts of almost 25 per cent in five years. As a second best, even more of the digitizing work should be contracted out than at present, to make savings which would then pay for extra staff. In this way, the Ordnance Survey could become a national centre for digital mapping incorporating a development team headed by a chief scientist.

But the House of Lords committee does see some difficulties on the horizon. Perhaps the most important is that of copyright. For many years, some small societies, such as the Chiltern Society, have been selling their own annotated versions of Ordnance Survey maps. But, in keeping with its new business-like image, the survey will not allow the sale of such competing maps in areas where it has produced an adequately detailed series of its own. With digital maps the problems may be much more difficult: the Ordnance Survey supplies base data from which any number of maps may be produced and which may be continually updated. Their Lordships decline to offer a solution to the problem.

\section{Czechoslovak science Large gap to bridge}

Planners in Czechoslovakia must reject slogans about the "omnipotence" of science and technology, since these can foster "dangerous illusions", deputy federal premier Jaromir Obzina warned last month. He was addressing the first meeting of the new State Commission for Scientific, Technical and Industrial Development, set up to close the gap between research and development on the one hand and the practical implementation of results on the other.

Before the establishment of the Czechoslovak commission, there had been considerable discussion in the press about the reasons for the gap. The general opinion was that there is no serious lack of funds for research - indeed, some allocations are not taken up or spent in full. Instead, the main cause appears to lie in the personalities of those responsible for implementing the results, a view reiterated by Mr Obzina in his reference before the comission to "insufficient coordination" between research and production and to "serious shortcomings" in management.

The purpose of the commission, $\mathrm{Mr} \mathrm{Ob}$ zina said, is to reveal the real causes of the shortcomings, and to deal with real problems. Energy should not be wasted on theoretical "pseudo-problems" and discussions, "however brilliant and witty they might be". But the task, he implied, is likely to be a long haul. The process of "socialist industrialization" may be compared with collectivization in agriculture "a programme of persistent work for a number of decades".

He warned the commission against associating itself with "naive people" who "today enthusiastically applaud scientific and technical progress", but whose personalities lack "persistence, diligence, perseverance and selflessness"'. Such people, he said, will be all too likely to turn against science when they find that "no cheap results have fallen into their laps".

Such remarks must, of course, be politically irreproachable, coming as they do from a deputy federal premier with the endorsement of party presidium member Milos Jakes, who pledged to the commission the "effective support" of the party "at all levels". In another context, and from a less eminent speaker, they might be construed as containing a certain veiled criticism not only of Marxism (which bases its validity on its "scientific" nature) but also of the Soviet Union where, during the later years of the Brezhnev era, there was undoubtedly a tendency to expect, in $\mathrm{Ob}$ zina's words, "some kind of miracle" as a result of that continuously repeated slogan "accelerated application of scientific and technical research findings in practice".

Vera Rich 